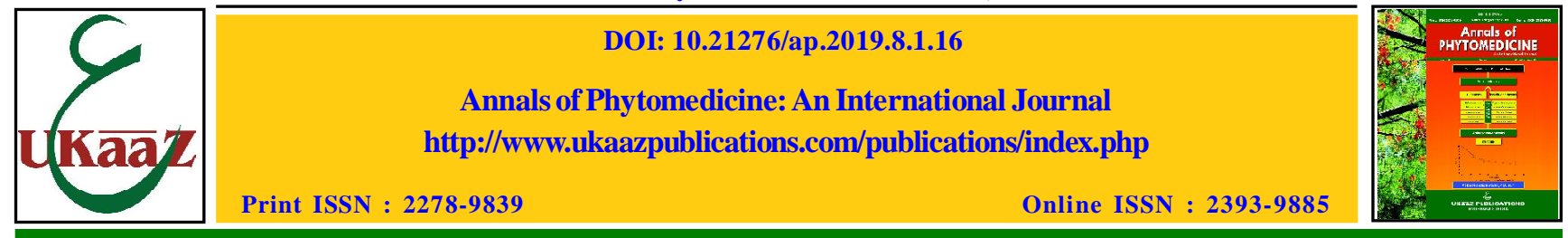

Original article

\title{
Phytochemical analysis and antioxidants activity of Silybum marianum (L.) Gaertn.
}

\author{
Kiran*, Pradeep Kumar*, Simran Kirti* and Altamash Ali Daudi \\ Department of Biochemistry, Dr. Rajendra Prasad Central Agricultural University, Pusa, Samastipur-848125, \\ Bihar, India \\ *Department of Agricultural Biotechnology and Molecular Biology, Dr. Rajendra Prasad Central Agricultural \\ University, Pusa, Samastipur-848125, Bihar, India
}

Received January 5, 2019: Revised February 25, 2019: Accepted February 27, 2019: Published online June 30, 2019

\begin{abstract}
The present study was an attempt to evaluate the phytochemical constituents and antioxidants potential of the methanol extract of leaves of Silybum marianum (L.) Gaertn., a known hepatoprotectant. For the evaluation of antioxidant activities of silymarin, assayed of total antioxidant activity, total reducing power (FRAP), 1,1-diphenyl2-picryl-hydrazyl free radical (DPPH), superoxide anion radical scavenging, hydrogen peroxide scavenging and ferrous ions $\left(\mathrm{Fe}^{2+}\right)$ chelating activity. The phytochemicals of silymarin were determined qualitatively and quantitatively by using standard methods. Qualitative analysis revealed that $S$. marianum is rich in phytochemicals, viz., alkaloids, terpenoids, steroids, phenols, flavonoids and glycosides. Quantification of flavonoids $(223 \mathrm{mg} / \mathrm{g})$ and phenols $(312$ $\mathrm{mg} / \mathrm{g}$ ) were also evaluated. The DPPH and chelating activity of silymarin were significantly high, i.e., $95 \%$ and $85 \%$, respectively at $21 \mu \mathrm{g} / \mathrm{ml}$ concentration, whereas FRAP and phosphomolybdenum reduction assay showed maximum activity, i.e., 0.88 and 0.089 , respectively at $21 \mu \mathrm{g} / \mathrm{ml}$ concentration. Free radicals scavengers like hydrogen peroxide and superoxide anions showed maximum inhibition percentage, i.e., $83 \%$ and $96 \%$, respectively at $21 \mu \mathrm{g} /$ $\mathrm{ml}$ concentration. The research study concludes that the leaves of $S$. marianum showed the highest antioxidant activities at $21 \mu \mathrm{g} / \mathrm{ml}$. It could be used in low concentrations in herbal medicine, pharmacological and food industry effectively.
\end{abstract}

Keywords: Silybum marianum (L.) Gaertn., silymarin, methanol extract, total antioxidant activity, FRAP, DPPH, radical scavenging

\section{Introduction}

Silybum marianum (L.) Gaertn. (milk thistle), family Asteraceae, is a hepatoprotective medicinal plant, used for the treatment of liver diseases likes hepatitis. Silybum is a type of weed which usually grows in an empty land, roadside areas and field. It is native to Europe and Asia. But, due to the presence of medicinal properties, it is cultivated for seeds, throughout the world. Approximately, $40 \%$ of patients with chronic hepatitis $\mathrm{C}$ virus (HCV) infection have reported the use of silymarin herbal products (Strader et al., 2002; Seeff et al., 2008). Silymarin is the collective name of cards marianus, milk thistle, blessed milk thistle, marian thistle, mary thistle, Saint Mary's thistle, mediterranean milk thistle, variegated thistle and flavonolignans. Extraction of milk thistle, is one of the most frequently reported herbal remedies, representing $72 \%$ of all herbals used by patients with HCV (Strader et al., 2002; Ghany et al., 2009).

It has three major components, silibinin, silydianin and silychristin. Silybinin is the main active component of silymarin. It efficiently

\footnotetext{
Author for correspondence: Dr. Kiran

Assistant Professor, Department of Biochemistry, Dr. Rajendra Prasad Central Agricultural University, Pusa, Samastipur-848125, Bihar, India

E-mail: kiran_pusa@yahoo.com

Tel.: +91-9431436488
}

Copyright (c) 2019 Ukaaz Publications. All rights reserved.

Email: ukaaz@yahoo.com; Website: www.ukaazpublications.com reduces and potentially regenerates the damaged hepatic tissues (Al-Anati et al., 2009). An antioxidant delay prevents and removes the oxidative damage to a target molecule (Sravanthi et al., 2013; Gireesha and Raju, 2016). DNA, lipids and proteins are usually damaged due to the action of free radicals (Halliwell and Gutteridge, 2010), leading to prevention, protection of various diseases like cancer, diabetes, cataract, ageing, etc., and as an oxygen scavengers (Bhatia et al., 1999; Sharma et al., 2003; Hogan et al., 2007; Mokhtari, 2008; Halliwell, 2011). Recently, silymarin has shown its potential as an anticholesterolaemic agent by enhancing ribosomal protein synthesis. This helps in regenerating hepatocytes (Zongguo et al., 2014).

An antioxidant is a highly stable molecule, they donate an electron to a destructively free radical and neutralize it, thus minimize its capacity to damage. Antioxidants delay cellular and molecular damage mainly through their free radical scavenging property (Lobo et al., 2010; Ahmad et al., 2010; Katerina et al., 2014; Ansari, 2016; Mathe, 2018; Mates et al., 2018). Antioxidants of plants origin are also used as anticancer, antimutagenic and antiageing agents (Cook and Samman, 1999). Secondary metabolites like phenols act as important antioxidant agents (Shaker et al., 2010). They are released naturally during different plant growth phases, while some are produced against stress conditions (Ahmad et al., 2010). As a result, antioxidants like thiols, ascorbic acid or polyphenols are often used as reducing agents. Natural antioxidants, especially present in 
medicinal plants, exhibits antioxidant, immunomodulatory, antifibrotic, antiproliferative, antiviral as well as vasodilatory activities (Pant et al., 2017).

To protect against this oxidative stress, the human body has its own system including various enzymes, proteins and vitamins, which are known as antioxidants. Ageing declines the production of such antioxidants, hence it requires an external source of antioxidants to defend free radicals (Gucin et al., 2003). Plants are good sources of antioxidants which provide protection against free radicals and have been strongly associated with reduced risk of chronic diseases (Tanizawa et al., 1992; Devasagayam et al., 2004). The antioxidant activity of these natural phytocontituents products is due to their redox properties, which allow them to act as reducing agents, hydrogen donators, singlet oxygen quenchers and metal chelators (Halliwell, 1997). Due to herbal and safer properties of silymarin and has no side effects is reported, from proper administration of designed curative prescribed amount (Nada et al., 2015).

The main objective of the silymarin study was to evaluate the phenols and flavonoids contents in the leaves of $S$. marianum, using methanol as a solvent and to assess their antioxidant potential.

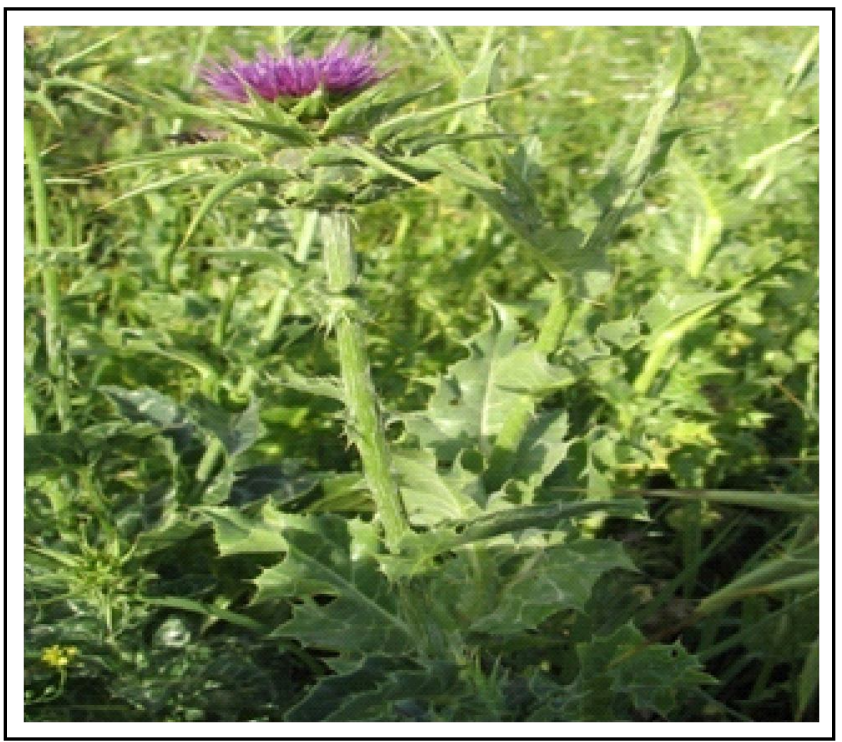

Figure 1: Habit of Silybum marianum (L.) Gaertn.

\section{Materials and Methods}

\subsection{Sample collection}

Samples of whole plant were collected in and around RPCAU, Pusa, Samastipur, Bihar, India. The plant material was identified by the corresponding author of this article. The voucher specimen (No: 246/PB/2017) was deposited in herbarium of this university. The samples were sundried and ground finely, sieved and stored in air tight containers for further analysis.

\subsection{Chemicals and reagents}

All chemicals used were of analytical grade, procured from HIMEDIA Laboratory Pvt. Ltd, India.

\subsubsection{Extract preparation}

$50 \mathrm{ml}$ of methanol was added to $5 \mathrm{gm}$ powdered material with periodic shaking for a week (it was stirred every $18 \mathrm{~h}$ using a sterilized glass rod), filtered and the filtrate was collected. This procedure was repeated three times with fresh methanol. The filtrates were pooled and concentrated at $40^{\circ} \mathrm{C}$ and evaporated to dryness and stored at $4^{\circ} \mathrm{C}$ in an airtight bottle. The extracts were dissolved in $10 \mathrm{ml}$ of methanol independently to get stock solutions.

\subsection{Qualitative phytochemical analysis}

Secondary metabolites present in the methanol extract of leaves of S. marianum was analysed by standard methods (Harbome, 1973; Trease and Evans, 1993; Zafar Mujeeb, 2002).

\subsection{Quantitative estimation}

\subsubsection{Estimation of total phenols by Folin-Ciocalteu reagent method}

Total phenolic compound contents were determined by the FolinCiocalteau method (Singleton et al., 1999) with slight modifications. The silymarin extract samples ( $1 \mathrm{ml}$ of different dilutions) were mixed with Folin-Ciocalteu reagent $(1 \mathrm{ml}, 1: 10$ diluted with distilled water) for $5 \mathrm{~min}$ and aqueous $\mathrm{Na}_{2} \mathrm{CO}_{3}(1 \mathrm{ml}, 1 \mathrm{M})$ was added. The mixture was allowed to stand for $15 \mathrm{~min}$ and the phenols were determined by UV-VIS double beam spectrophotometer at $765 \mathrm{~nm}$. Gallic acid was used as the standard. The total phenol content was expressed in terms of gallic acid equivalent $(\mathrm{mg} / \mathrm{g})$.

\subsubsection{Estimation of total flavonoids by $\mathrm{AlCl}_{3}$ method}

Aluminium chloride was used to determine the total flavonoids (Chang et al., 2002) with slight modifications. $1 \mathrm{ml}$ of methanol extract of leaves of silymarin was mixed with $0.5 \mathrm{ml}$ of $10 \%$ aluminium chloride, $0.5 \mathrm{ml}$ of $1 \mathrm{M}$ potassium acetate and $1 \mathrm{ml}$ of distilled water. It was incubated at room temperature for $30 \mathrm{~min}$. The absorbance of the reaction mixture was measured at $415 \mathrm{~nm}$ with UV-VIS double beam spectrophotometer. The total flavonoid contents were expressed as in terms of quercetin equivalent $(\mathrm{mg} / \mathrm{g})$ which served as the standard.

\subsection{Antioxidant activities}

\subsubsection{DPPH radical scavenging assay}

The antioxidant activity of methanol extract of leaves of silymarin was measured on the basis of the scavenging activity of the stable 2, 2- diphenyl-1-picrylhydrazyl (DPPH) free radical by BrandWilliams et al. (1995) with slight modifications. $1 \mathrm{ml}$ of $0.1 \mathrm{mM}$ DPPH solution in methanol was mixed with the extract. Quercetin was taken as the reference standard. Blank was $1 \mathrm{ml}$ methanol and $1 \mathrm{ml}$ DPPH solution. The decrease in absorbance was measured at $517 \mathrm{~nm}$ after $30 \mathrm{~min}$ in dark using UV-Vis spectrophotometer. The inhibition \% was calculated using the following formula:

$$
\text { DPPH scavenging effect } \%=(1-\mathrm{As} / \mathrm{Ac}) \times 100
$$

where Ac is the absorbance of control and As is the absorbance of the test sample.

\subsubsection{Chelating activity on ferrous ion $\left(\mathrm{Fe}^{+2}\right)$}

The chelation of $\mathrm{Fe}^{2+}$ by methanol extract of leaves of silymarin was estimated by the method of Dinis et al. (1996). Methanol extract was added in different concentrations ( 3 to $21 \mu \mathrm{g} / \mathrm{ml}$ ) to a solution of $1 \mathrm{mM} \mathrm{FeCl}(0.05 \mathrm{ml})$. The reaction was initiated by the addition of $1 \mathrm{mM}$ ferrozine $(0.1 \mathrm{ml}$, ) and the mixture was shaken vigorously and left standing at room temperature for $10 \mathrm{~min}$. After the mixture had reached equilibrium, the absorbance of the solution was 
measured spectrophotometrically at $562 \mathrm{~nm}$. EDTA was used as the standard reference. The percentage of inhibition of ferrozine $\mathrm{Fe}^{+2}$ complex formation was calculated by using the following formula given below:

Inhibition $\%$ of $\mathrm{Fe}^{+2}=(1-\mathrm{As} / \mathrm{Ac}) \times 100$

where Ac is the absorbance of control and As is the absorbance of the sample (Dorman et al., 2003).

\subsubsection{Ferric $\left(\mathrm{Fe}^{3+}\right)$ reducing power assay (FRAP)}

The reducing power of methanol extract of leaves of silymarin was determined by a slightly modified method of Oyaizu (1986). $1 \mathrm{ml}$ of each plant extract concentration (3-21 $\mathrm{mg} / \mathrm{m} \mathrm{S}$. marianum) was mixed with phosphate buffer $(1 \mathrm{ml}, 0.2 \mathrm{M}, \mathrm{pH}$ 6.6) and potassium ferricyanide $\left(\mathrm{K}_{3} \mathrm{Fe}(\mathrm{CN})_{6}\right)(1 \mathrm{ml}, 1 \%)$. The mixtures were then incubated at $50^{\circ} \mathrm{C}$ for $20 \mathrm{~min} .1 \mathrm{ml}$ of trichloroacetic acid $(10 \%)$ was added to each mixture, which was then centrifuged for $10 \mathrm{~min}$ at $5000 \mathrm{rpm}$. The upper layer of the solutions $(1 \mathrm{ml})$ was mixed separately with distilled water $(1 \mathrm{ml})$ and $\mathrm{FeCl}_{3}(0.5 \mathrm{ml}, 0.1 \%)$, and the absorbance was measured at $700 \mathrm{~nm}$ using a spectrophotometer. Ascorbic acid was used as the standard reference.

\subsubsection{Total antioxidant capacity (Phosphomolybdenum reduction) assay}

The total antioxidant capacity of the methanol extract of leaves of silymarin was evaluated by the phosphomolybdenum reduction assay method according to the procedure described by Prieto et al. (1999). The assay is based on the reduction of Mo (VI) to Mo (V) by the methanol extract of leaves of silymarin and subsequent formation of green phosphate/Mo (V) complex at acid $\mathrm{pH} .1 \mathrm{ml}$ of various concentrations $(3-21 \mu \mathrm{g} / \mathrm{ml})$ of the extract were combined with $1 \mathrm{ml}$ of reagent solution $(0.6 \mathrm{M}$ sulfuric acid, $28 \mathrm{mM}$ sodium phosphate and $4 \mathrm{mM}$ ammonium molybdate) and incubated at $95^{\circ} \mathrm{C}$ for $90 \mathrm{~min}$. The absorbance of the reaction mixture was measured at $695 \mathrm{~nm}$ using a spectrophotometer. Gallic acid was used as the standard reference.

\subsubsection{Hydrogen peroxide scavenging assay}

The hydrogen peroxide scavenging assay was carried out, following the procedure of Ruch et al. (1989). The principle of this method is there to decrease in absorbance of $\mathrm{H}_{2} \mathrm{O}_{2}$ upon oxidation of $\mathrm{H}_{2} \mathrm{O}_{2}$. A solution of $40 \mathrm{mM} \mathrm{H}_{2} \mathrm{O}_{2}$ was prepared in $0.1 \mathrm{M}$ phosphate buffer (pH 7.4). Silymarin at the $\mathrm{mg} / \mathrm{ml}$ concentration in $3.4 \mathrm{ml}$ phosphate buffer was added to $0.6 \mathrm{ml}$ of $\mathrm{H}_{2} \mathrm{O}_{2}$ solution $(40 \mathrm{mM})$ and the absorbance of the reaction mixture was recorded at $230 \mathrm{~nm}$. A blank solution contained the sodium phosphate buffer without $\mathrm{H}_{2} \mathrm{O}_{2}$. The concentration of $\mathrm{H}_{2} \mathrm{O}_{2}$ ion of hydrogen peroxide $(\mathrm{mM})$ in the assay medium was determined by using a standard (catechin) curve and was calculated using the following equation:

$$
\mathrm{H}_{2} \mathrm{O}_{2} \text { scavenging effect } \%=(1-\mathrm{As} / \mathrm{Ac}) \times 100
$$

where Ac is the absorbance of control and As is the absorbance of the sample (Manach et al., 2004).

\subsubsection{Superoxide anion radical scavenging activity}

Superoxide radical scavenging activity of silymarin was performed according to the method of Beauchamp and Fridovich (1971), described by Zhishen et al. (1999) with slight modification. Superoxide radicals are generated in riboflavin, methionine, illuminate and assayed by the reduction of NBT to form blue formazan. All solutions were prepared in a $0.05 \mathrm{M}$ phosphate buffer (pH 7.8). The photo-induced reactions were performed using fluorescent lamps $(20 \mathrm{~W})$. The concentration of silymarin in the reaction mixture was $30 \mathrm{mg} / \mathrm{ml}$. The total volume of the reaction mixture was $3 \mathrm{ml}$ and the concentrations of the riboflavin, methionine and NBT were $1.33-10^{-5}, 4.46-10^{-5}$ and $8.15-10^{-8} \mathrm{M}$, respectively. The reaction mixture was illuminated at $25^{\circ} \mathrm{C}$ for $40 \mathrm{~min}$. The photochemically reduced riboflavin generated $\mathrm{O}_{2}^{-}$which reduced NBT to form blue formazan. The unilluminated reaction mixture was used as a blank. The absorbance was measured at $560 \mathrm{~nm}$. Silymarin was added to the reaction mixture, in which $\mathrm{O}_{2}^{-}$was scavenged, thereby inhibiting the NBT reduction. Decreased absorbance of the reaction mixture indicates increased superoxide anion scavenging activity. The percentage of superoxide anion scavenged was calculated by using the following formula:

$$
\mathrm{O}_{2}^{-} \text {scavenging effect } \%=(1-\mathrm{As} / \mathrm{Ac}) \times 100
$$

where Ac is the absorbance of the control and As is the absorbance of silymarin and BHT was used as the standard.

\subsection{Statistical analysis}

The experimental results were performed in triplicate. The data were recorded as Mean \pm standard deviation and analysed by SPSS (operating system windows 2007). One-way analysis of variance (ANOVA) was performed by procedures. Significant differences between means were determined by Duncan's Multiple Range tests, and $p \leq 0.05$ was regarded as significant and $p \leq 0.01$ was very significant.

\section{Results}

The formulations of drugs are based on the extraction of natural and synthetic antioxidants. It is mainly used for the prevention and treatment of complex diseases like atherosclerosis, stroke, diabetes, Alzheimer's disease and cancer (Sofowora, 1999). The methanol extract of leaves of silymarin was subjected to various qualitative chemical tests (Ganapaty et al., 2007). The methanol extract showed the presence of phytochemical constituents such as alkaloids, terpenoids, steroids, flavonoids, phenol compounds and glycosides as presented in Table 1. The qualitative analysis showed the major presence of phenols and flavonoids contents such as $312 \mathrm{mg} / \mathrm{g}$ and $223 \mathrm{mg} / \mathrm{g}$, respectively as presented in Table 2 .

Table 1: Qualitative estimation of phenols and flavonoids of methanol extract of leaves of $S$. marianum

\begin{tabular}{|l|l|c|}
\hline Phytoconstituents & Chemical reagents & Results \\
\hline Alkaloids & Dragendorf's reagent & ++ \\
& Wagner's reagent & ++ \\
Terpenoids & $\mathrm{CHCl}_{3}+$ conc. $\mathrm{H}_{2} \mathrm{SO}_{4}$ & ++ \\
Steroids & Libermann-Burchard's reagent & ++ \\
Phenols & $\mathrm{FeCl}_{3}$ solution & ++ \\
Flavonoids & Shinoda $(\mathrm{NaOH}$ solution) test & ++ \\
& Magnesium filaments $+\mathrm{HCl}$ test & ++ \\
Glycosides & Fehling's test & ++ \\
& Molisch's test & ++ \\
\hline
\end{tabular}

++ :Strongly present, + :Mild present and - : complete absent 
Table 2: Quantitative estimation of phenols and flavonoids of methanol extract of leaves of $S$. marianum

\begin{tabular}{|c|l|c|}
\hline S.No. & Components & Concentration $(\mathbf{m g} / \mathbf{g})$ \\
\hline 1. & Phenols & $312 \pm 5.6$ \\
2. & Flavonoids & $223 \pm 3.1$ \\
\hline
\end{tabular}

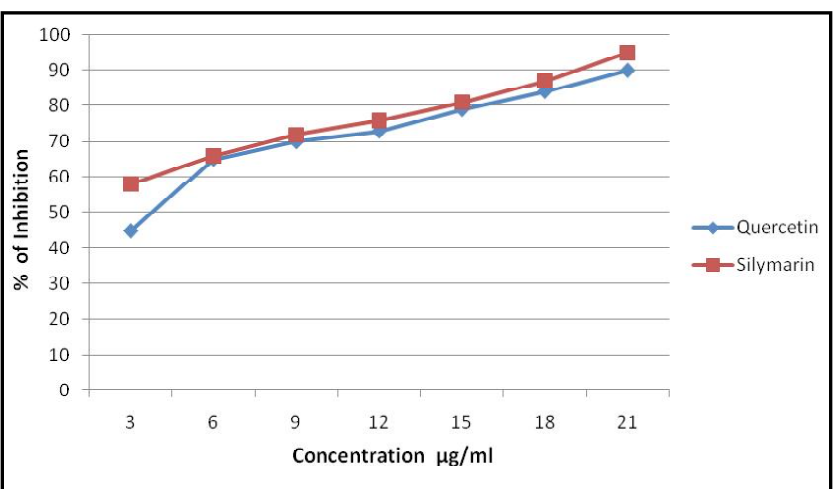

Figure 2: DPPH radical scavenging assay of $S$. marianum.

Table 3: Scavenging activities of methanol extract of leaves of silymarin

\begin{tabular}{|c|c|c|c|c|c|c|c|c|}
\hline $\begin{array}{l}\text { Scavenging } \\
\text { radicals }\end{array}$ & \begin{tabular}{|l|} 
Standard \\
$\mu \mathrm{g} / \mathrm{ml}$
\end{tabular} & & & Conc & $\begin{array}{l}\text { entrati } \\
\mu / \mathrm{ml}\end{array}$ & & & \\
\hline & & 3.00 & 6.00 & 9.00 & 12.00 & 15.00 & 18.00 & 21.00 \\
\hline DPPH & Quercetin & 45.00 & 65.00 & 70.00 & 73.00 & 79.00 & 84.00 & 90.00 \\
\hline & Silymarin & 58.0 & 66.00 & 72.00 & 76.00 & 81.00 & 87.00 & 95.00 \\
\hline $\begin{array}{l}\text { Chelating } \\
\text { Activity }\end{array}$ & EDTA & 15.00 & 25.00 & 30.00 & 50.00 & 70.00 & 75.00 & 87.00 \\
\hline$\left(\mathrm{Fe}^{+2}\right)$ & Silymarin & 17.00 & 22.00 & 38.00 & 62.00 & 72.00 & 73.00 & 85.00 \\
\hline FRAP & $\begin{array}{l}\text { Ascorbic } \\
\text { acid }\end{array}$ & 0.35 & 0.48 & 0.60 & 0.65 & 0.69 & 0.75 & 0.84 \\
\hline$\left(\mathrm{Fe}^{+3}\right)$ & Silymarin & 0.36 & 0.45 & 0.55 & 0.63 & 0.65 & 0.71 & 0.88 \\
\hline
\end{tabular}

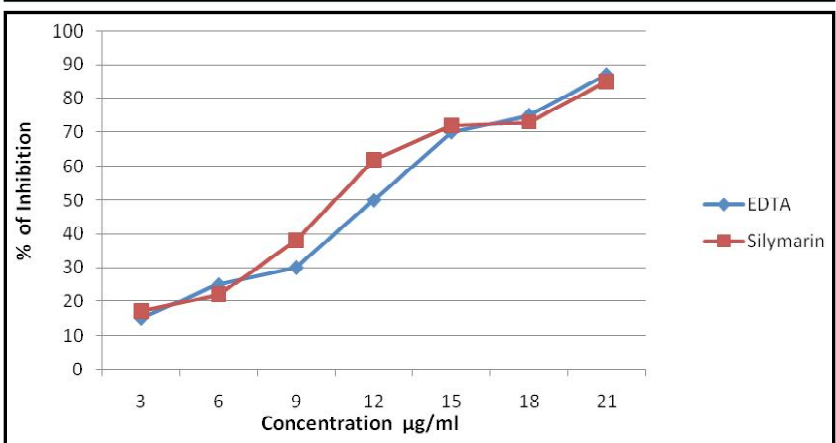

Figure 3: $\mathrm{Fe}^{2+}$ chelating assay of $S$. marianum.

The antioxidant activity of methanol extract of leaves of silymarin was evaluated by DPPH free radical scavenging assay, $\mathrm{Fe}^{2+}$ chelating assay, ferric $\left(\mathrm{Fe}^{3+}\right)$ reducing power assay (FRAP) and total antioxidant capacity (phosphomolybdenum reduction assay) and the results were presented in the Tables 3 and 4 . The increase in percentage of DPPH radicals scavenging activity as well as $\mathrm{Fe}^{2+}$ chelating activity increases with an increase in concentrations of silymarin. The maximum DPPH radical scavenging activity showed the $\%$ of inhibition was 95.0 and the standard quercetin was 90.0 at $21 \mu \mathrm{g} / \mathrm{ml}$ concentration (Figure 1). The maximum chelating activity of silymarin was 85.0 and the standard EDTA was 87.0 at $21 \mu \mathrm{g} / \mathrm{ml}$ concentration (Figure 2).

The ferric reducing power (FRAP) assay showed maximum activity of 0.88 and also the phosphomolybdenum reduction assay showed maximum activity of 0.089 at $21 \mu \mathrm{g} / \mathrm{ml}$ concentration, which were compared with the standards showed the activity of 0.84 and 0.080 , respectively. The ascorbic acid as standards was used for FRAP and gallic acid as standard used for phosphomolybdenum reduction assay (Figures 3 and 4).

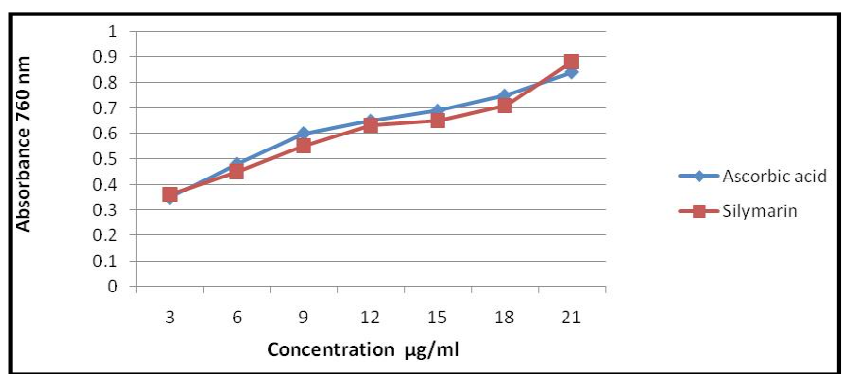

Figure 4: Reducing power assay (FRAP) of S. marianum.

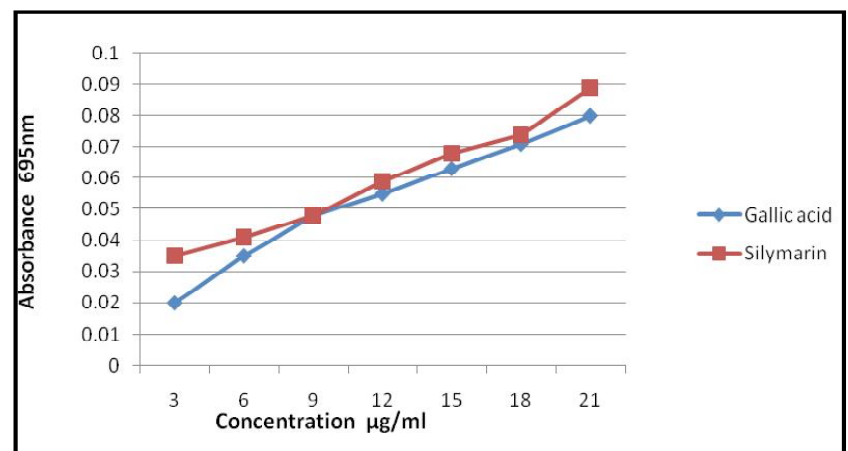

Figure 5: Phosphomolybdenum reduction assay of $S$. marianum.

Hydrogen peroxide scavenging activity of silymarin at $21 \mu \mathrm{g} / \mathrm{ml}$ was found to be $83 \%$, whereas standard catechin was found to be $81 \%$ (Figure 5). The results showed that the silymarin has an effective hydrogen peroxide scavenging activity (Figure 6). At the above concentration, the hydrogen peroxide scavenging effect of silymarin was more than standard.

Table 4: Scavenging activities $\mu \mathrm{g} / \mathrm{ml}$ of methanol extract of leaves of $S$. marianum

\begin{tabular}{|l|l|r|r|r|r|r|r|r|}
\hline $\begin{array}{l}\text { Scavenging } \\
\text { radicals }\end{array}$ & $\begin{array}{l}\text { Standard } \\
\boldsymbol{\mu g} / \mathbf{m l}\end{array}$ & \multicolumn{6}{|c|}{ Concentration $\mu / \mathbf{m l}$} \\
\hline & & 3.00 & 6.00 & 9.00 & 12.00 & 15.00 & 18.00 & 21.00 \\
\hline $\begin{array}{l}\text { Total antioxi- } \\
\text { dants activity }\end{array}$ & $\begin{array}{l}\text { Gallic } \\
\text { acid } \\
\text { Silymarin }\end{array}$ & 0.02 & 0.04 & 0.05 & 0.06 & 0.06 & 0.07 & 0.80 \\
\hline $\begin{array}{l}\text { Hydrogen } \\
\text { peroxide } \\
\text { scavenging } \\
\text { activity }\end{array}$ & Satechin & 31.00 & 42.00 & 58.00 & 64.00 & 73.00 & 78.00 & 81.00 \\
\hline $\begin{array}{l}\text { Superoxide } \\
\text { anion } \\
\text { radical } \\
\text { activity }\end{array}$ & BHT & 28.00 & 48.00 & 52.00 & 73.00 & 78.00 & 80.00 & 83.00 \\
\hline
\end{tabular}




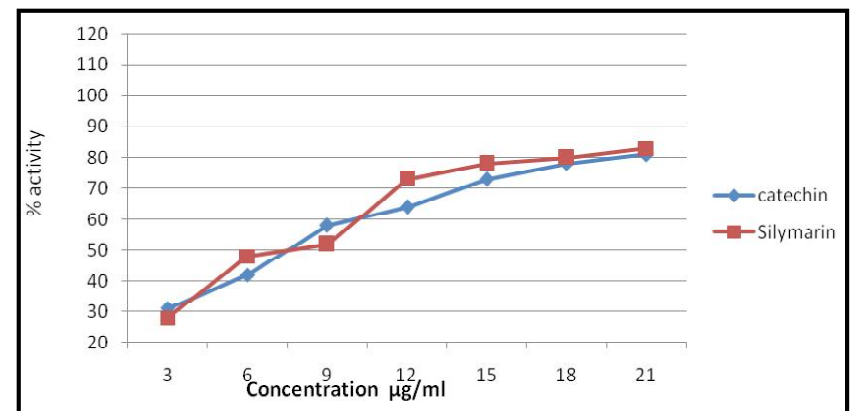

Figure 6: Hydrogen peroxide assay of S. marianum.

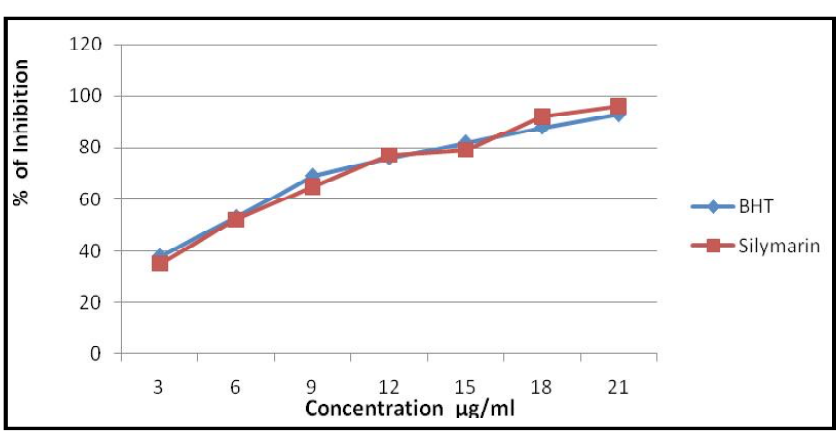

Figure 7: Superoxide anion radical assay of $S$. marianum.

The inhibition of superoxide anion radicals' generation by silymarin was somewhat higher than standard BHT (Figure 7). It was seen in the inhibition of superoxide radical of silymarin which was found to be $96.0 \%$ as compared to the standard $93 \%$ to be at $21 \mu \mathrm{g} / \mathrm{ml}$ concentration.

\section{Discussion}

Flavonoids and plant phenolic compounds possess highly antioxidant properties and they have abilities to trapping free radicals and reactive oxygen species such as singlet oxygen, free radicals and hydroxyl radicals. They play an important role in stabilizing lipid peroxidation (Gulcin and Dastan, 2007; Gulcin, et al., 2006) by scavenging and neutralizing free radicals, quenching singlet and triplet oxygen. They are continuously prevented from generating free radical by breaking of a chain reaction of the fatty acids during oxidative stress. The observation of the present study showed that silymarin plants have also high content of phytochemicals like phenols and flavonoids, i.e., 312 and $223 \mathrm{mg} / \mathrm{g}$, respectively (Table 2 ). The study revealed that the phenols and flavonoids of plants are correlated in metabolism and involved in different types of biosynthesis processes like shikimate, pentose phosphate, phenylpropanoid pathways, etc. (Singleton et al., 1999).

Plants phenolic and flavonoids, both compounds are protecting elements of the cells means that they act as a defence mechanism. Other than this, they are also involved in the formation of structural polymers like lignin, attractants of plants pigments like carotenoids and flavonols, defence response chemicals like tannins and phytoalexins, UV screen like flavonoids, etc. In humans, phenolic compounds act as antioxidants, anti-ageing, anti-inflammatory and anti-proliferative activities, etc. Therefore, if the foods contain high antioxidants activities, indicate that reduced the chances of chronic diseases like diabetes, cardiovascular and cancer. So, the antioxidants activities of phytochemical constituents mainly phenolics, flavonoids and flavonols are attributed to the medicinal effect of the plants (Miliauskas et al., 2004). It is also known that phenolic compounds are strongly chain-breaking antioxidants (Shahidi and Wanasundara, 1992). The scavenging properties of phenolic compounds are due to the presence of hydroxyl groups (Hateno et $a l .$, 1987). Other than the hydroxyl group, the o-dihydroxy group is also showing very strong antioxidants activities as well as scavenging activities.

The total antioxidant activities of plants are assessed by DPPH radical scavenging assay, $\mathrm{Fe}^{+2}$ chelating assay, FRAP assay and phosphomolybdenum reduction assay. The activities of DPPH are increased, showed the high contents of phenolic components such as flavonoids, phenolic acids and phenolic diterpenes (Oyaizu, 1986). The same studies were conducted by Chandra et al. (2014) and Sravanthi and Rao, (2014). In DPPH assay, the antioxidants present on silymarin reduce the violet coloured stable 2,2-diphenyl1-picryl-hydrazyl radicals to the yellow coloured 2, 2-diphenyl-1picryl hydrazine. The molecules of 2,2-diphenyl-1-picryl-hydrazine are identified as a stable free radical by the decolourisation of used electrons of the molecules. The different doses response of DPPH radical scavenging activity of silymarin was depicted in Figure 2.

The transition metal ion, $\mathrm{Fe}^{2+}$ have the capability to move single electron by virtue of which, it can allow the formation and propagation of many radical reactions, even starting with relatively non-reactive radicals (Dinis et al., 1996). The main strategy to avoid the generation of ROS that is associated with redox active metal catalysis involves chelating of the metal ions.

Metal-chelating property is measured of the antioxidant activity based on absorbance measurement of $\mathrm{Fe}^{2+}$ p-ferrozine complex after prior treatment of $\mathrm{Fe}^{2+}$ ion solution with the test material. Ferrozine complex compound formation with free $\mathrm{Fe}^{2+}$ ions but $\mathrm{Fe}^{2+}$ not bound to other chelators, hence decrease the amount of ferrozine $\mathrm{Fe}^{2+}$ complex formed after the treatment of the presence of antioxidant chelators.

The ferrozine $\mathrm{Fe}^{2+}$ complex develops the red colour compound with the absorbance can be measured of $562 \mathrm{~nm}$ wavelength of light (Koksal et al., 2008). EDTA is a strong metal chelator. So, it is used as a standard metal agent in this study. Silymarin has a high capacity for iron binding, suggesting that its main action as a peroxidation inhibitor may be related to its iron binding capacity.

In this assay, silymarin interfered with the development of the ferrous-ferrozine complex. It suggests that silymarin has chelating property and is able to capture $\mathrm{Fe}^{2+}$ ion before ferrozine. Silymarin may chelate the $\mathrm{Fe}^{2+}$ with its $\mathrm{OH}^{-}$group (Figure 3). Fiorucci and coworkers confirmed that quercetin chelated metal ion in the same way (Fiorucci et al., 2007). The DPPH (2, 2-diphenyl-2-picryl hydrazyl) free radical scavenging activity and $\mathrm{Fe}^{2+}$ show the chelating activity. In non-antioxidant enzyme like FRAP is known for powerful free radicals scavengers and always they are used in the laboratory for measuring maximum trapping of oxidant radicals. The presence of antioxidant, the $\mathrm{Fe}^{3+} /$ ferricyanide complex reduce to $\mathrm{Fe}^{2+}$ ferrous form (Benzie et al., 1996).

Reduction of $\mathrm{Fe}^{3+}$ solution is often used as an indicator of electron accepting activity, which is an important mechanism of phenolic. An antioxidant activity can be correlated with other antioxidant properties (Gulcin et al., 2006). By estimating the formation of 
pearl's prussian blue at $700 \mathrm{~nm}$, it is conceivable to determine the concentration of ferrous $\left(\mathrm{Fe}^{2+}\right)$ ions. Increase in absorbance of the reaction solution signifies to reducing the power of the extract (Figure 4). The reducing power assay showed greater reduction capacity compared with the standard ascorbic acid curve. Hence, silymarin plant proved to be higher phytoconstituents with the potential antioxidant activity.

The phosphomolybdenum reduction assay was based on the decrease of the oxidation state of Mo (VI) to Mo (V), in presence of antioxidant and consequent formation of a green phosphate Mo (V) complex on higher temperature and acidic $\mathrm{pH}$. The phosphomolybdenum reduction assay increases with increase in concentration (Figure 5). Hydrogen peroxide is generated by several oxidase enzymes such as catalase, peroxidase, superoxide dismutase, glutathione peroxidase and ascorbic oxidase.

There is increasing evidence that $\mathrm{H}_{2} \mathrm{O}_{2}$, either directly or indirectly via its reduction product $\mathrm{OH}^{-}$, act as a messenger molecule in the synthesis and activation of inflammatory mediators. Secondary messenger permeable to the membrane and oxidize slowly in various compounds. The hydrogen peroxide scavenging capacity of silymarin plant was depicted in Figure 6. Silymarin had effective hydrogen peroxide scavenging activity. $\mathrm{H}_{2} \mathrm{O}_{2}$ is toxic for cell and induces cell death because they degrade many cellular organelles like mitochondria and chloroplast or energy producing systems. Hydrogen peroxide inactivated glyceraldehydes-3-phosphate dehydrogenase, a glycolytic enzyme, the imitation of apoptosis process (Hyslop et al., 1988).

The free radical reaction is most accepted as a common mechanism of lipid peroxidation. Free radical scavengers may directly react with and quench peroxide radicals to terminate the lipid peroxidation chain reactions and enhance the quality as well as the stability of food products. Superoxide anion has played an important role in the formation of other ROS such as $\mathrm{H}_{2} \mathrm{O}_{2}, \mathrm{OH}$ radical and singlet oxygen which induces oxidative damage in the biomolecules. Superoxide free radicals are strongly oxidizing agents; they are commonly formed and their effects can be magnified because they are produced to other type of the free radicles in metabolic reactions in the cells. In this assay, the superoxide reduces NBT yellow dye to formazan blue colour, the activity measured on visible wavelength $560 \mathrm{~nm}$ through spectrophotometer. Antioxidants are capble to inhibit the blue NBT formation (Parejo et al., 2002).

The decrease of absorbance at $560 \mathrm{~nm}$ with antioxidant indicates the consumption of superoxide in the reaction mixture. The uniluminated reaction mixture was used as a blank. It showed the maximum inhibition of superoxide radical generatin by $21 \mu \mathrm{g} / \mathrm{ml}$ concentration of silymarin with respect to standards (BHT) as depicted as in Figure 7.

\section{Conclusion}

The results of the present investigation clearly showed, that the silymarin plants have various phytochemical content and their respective antioxidant activities. Secondary metabolites of plant are a mostly phenolic compound which possesses on their structure a benzene ring with hydroxyl group. These metabolites are ubiquitously distributed in the plant and their parts; exhibit a wide range of pharmacological and curative properties, including antiinflammatory, anticarcinogenic, vasodilatory actions. Plants are the good resources for natural antioxidants. Antioxidant is one of the vital for preventing in vivo oxidative damages. The plants were used to evaluate the antioxidant potential using DPPH free radical scavenging assay, $\mathrm{Fe}^{2+}$ chelating assay, ferric $\left(\mathrm{Fe}^{3+}\right)$ reducing power assay, phosphomolybdenum reduction assay methods, chelating activities, hydrogen peroxide assay and superoxides anion radical scavenging activity. The methanol extract of silymarin showed higher phenols content as well as flavonoids content and it contributes to the higher antioxidant activity. Considering the results obtained, it could be concluded that the plant contains essential phytochemical constituents and possess active antioxidant property. The different studies are also carried out to find active component of the extract and to confirm the mechanism of action in animals. A number of beneficial health effects of silymarin have been reported. The above discussion revealed that silymarin can be used as pharmaceutical products, for decreasing the formation of toxic oxidation, keeping nutritional quality and increasing shelf life of pharmaceuticals.

\section{Acknowledgements}

The research study related to this work was carried out at the Biochemistry Department, Faculties of Basic Sciences and Humanities, Dr. Rajendra Prasad Central Agrilcultural University, Pusa, Samastipur, Bihar, India. We would like to acknowledge the support given by the departmental technical staff for the preparation of the manuscript and the statistical analysis.

\section{Conflict of interest}

The authors declare that no conflict of interest exists in the course of conducting this research. All authors had final decision regarding the manuscript and the decision to submit the findings for publication.

\section{References}

Ahmed-Belkacem, A.; Ahnou, N. and Barbotte, L. (2010). Silibinin and related compounds are direct inhibitors of hepatitis C virus RNAdependent RNA polymerase. Gastroenterology, 138(3):11121122.

Al-Anati, L.; Essid, E.; Reinehr, R. and Petzinger, E. (2009). Silibinin protects OTA-mediated TNF-alpha release from perfused rat livers and isolated rat khpffer cells. Mol. Nutr. Food Res., 53:460-446.

Ansari, S.H. (2016). Globalization of herbal drugs. Ann. Phytomed., 5(2).: $1-5$.

Beauchamp, C. and Fridovich, I. (1971). Superoxide dismutase: Improved assays and an assay applicable to acrylamide gels, Anal. Biochem., 44:276-287.

Benzie, I.F.F. and Strain, J.J. (1996). The ferric reducing ability of plasma as a measure of 'antioxidant power': The FRAP assay. Anal. Biochem., 239:70-76.

Bhatia, N.; Zhaoj; Wolf, D.M. and Agarwal, R. (1999). Inhibition of human carcinoma cell growth and DNA synthesis by silibinin, an active constitute of milk thistle: Comparison with silymarin. Cancer Letters, 147(1-2):77-84.

Brand-williams, W.; Cuvelier, M.E. and Berset, C. (1995). Use of free radical method to evaluate antioxidant activity. Lebensmittel Wissenschaft and Technologie, 28(1):25-30.

Chang, C.; Yang, M.; Wen, H. and Chern, J. (2002). Estimation of total flavonoids content in propolis by two complementary colorimetric methods. J. Food Drug Analysis, 10:178-182.

Chandra, S.; Khan, S.; Avula, B.; Lata, H.; Yang, M.H.; ElSohly, M.A.; and Khan, I.A. (2014). Assessment of total phenolic and flavonoid content, 
antioxidant properties, and yield of aeroponically and conventionally grown leafy vegetables and fruit Crop: A comparative study. Evid Based Complement Alternat. Med., $\mathrm{pp}: 252-275$.

Cook, N.C. and Samman, S. (1996). Flavonoids chemistry metabolism, cardioprotective effects and dietary sources. J. Nutr. Biochemistry, 7:66-76.

Devasagayam, T.P.A.; Tilak, J.C. and Boloor, K.K. (2004). Review: Free radical and antioxidants in human health. Curr Stat Fut Pros JAPI, 53: 794-804

Dinis, T.C.P.; Madeira, V.M.C. and Almeida, M.L.M. (1996). Action of phenolic derivates (acetoaminophen, salycilate and 5-aminosalycilate) as inhibitors of membrane lipid peroxidation and as peroxyl radical scavengers. Arch. Biochem. Biophys, 315:161-169.

Dorman, H.J.D.; Peltoketo, A.; Hiltunen, R. and Tikkanen, M.J. (2003). Characterization of the antioxidant properties of de odorised aqueous extracts from selected Lamiaceae herbs. Food Chem., 83:255-262.

Fiorucci, S.B.; Golebýowski, J.; Cabro Bass, D. and Antonczak, S. (2007). DFT study of quercetin activated forms involved in antiradical, antioxidant, and prooxidant biological processes. J. Agric. Food Chem., 55:903-911.

Ganapaty, S.; Chandrashekhar, V.M.; Chitme, H.R. and Lakshmi, N.M. (2007). Free radical scavenging activity of gossypin and nevadensin: An in vitro relation. Indian Journal of Pharmacology, 39:281-283.

Ghany, M.G.; Strader, D.B.; Thomas, D.L. and Seeff, L.B. (2009). Diagnosis, management, and treatment of hepatitis C: An update. Hepatology, 49(4):1335-1374

Gireesha, J. and Raju, N.S. (2016). Phytochemical analysis, antibacterial and antioxidant potential of Acronychia pedunculata (L.) Miq. Ann Phytomed., 5(2):147-151.

Gucin, I.; Oktay, M.; Kirecci, E. and Kufrevioglu, O.I. (2003). Screening of antioxidant and antimicrobial activities of anise (Pimpinellam anisum L.) seed extracts. Food Chem., 83:371-382.

Gulcin, I. and Dastan, A. (2007). Synthesis of dimeric phenol derivatives and determination of in vitro antioxidant and radical scavenging activities. J. Enz. Inhib. Med. Chem., 22(6):685-695.

Gulcin, I.; Elias, R.; Gepdiremen, A. and Boyer, L. (2006). Antioxidant activity of lignans from fringe tree (Chionanthus virginicus L.). Eur. Food Res. Technol., 223:759-767.

Habil Akos, Mathe (2018). Remarks to the recent trends in exploring medicinal plant diversity. Ann. Phytomed., 7(2):1-5.

Halliwell, B. (1997). Antioxidants in human health and disease. Annual Rev. Nut., 6:33-50.

Halliwell, B. and Gutteridge, J.M. (2010). Antioxidants: Molecules, Medicines and Myths. Biochem. Biophys. Res. Commun., 393(4): 561-564.

Halliwell. B. (2011). Free radcals and antioxidants. Trends Pharmacol. Sci., 32(3): 125-130.

Harbome, J.B. (1973). Pytochemical Methods. Chapman and Hall Ltd., London, 49:188.

Hateno, T.; Edamatsu, R. and Mari, A. (1987). Effects of interactions of tannins and co-existing substances VI, effects of tannins and related polyphenols on superoxide anion radical and a DPPH radical. Chemistry and Pharmceutical Bulletin, 37:2016-2021.

Hogan, F.S.; Krishnegowda, N.K.; Mikhailova, M. and Kahlenberg, M.S. (2007). Flavonoid, silibinin, inhibits proliferation and promotes cell-cycle arrest of human colon cancer. J. Surg. Res., 143:58-65.
Hyslop, P.A.; Hinshaw, D.B.; Halsey, W.A.; Schraufstatter, I.U.; Sauerheber, R.D.; Spragg, R.G.; Jackson, J.H. and Cochrane, C.G. (1988). Mechanisms of oxidant-mediated cell injury. The glycolytic and mitochondrial pathways of ADP phosphorylation are major intracellular targets inactivated by hydrogen peroxide. J. Biol. Chem., 263:1665-1675.

Katerina, T.; Hana, K.; Klara, P.; Svatopluk, B. and Petr K. (2014). Cytotoxicity and antioxidative effects of herbal and fruit extracts in vitro. Food Biophysics. 9(3):267-276.

Koksal, E.; Gulcin, I.; Beyza, S.; Sarikaya, O.; and Bursal, E. (2008). In vitro antioxidant activity of silymarin. Journal of Enzyme Inhibition and Medicinal Chemistry, 24(2):395-405.

Lobo, V.; Patil, A.; Phatak, A.; and Chandra, N. (2010). Free radicals, antioxidant and functional foods: Impact on human health. Pharmacogn Rev., 4(8):118-126.

Mates C. Ionut; Spinu Marina; Pall Emoke; Brudasca Florinel; Suatean Monica; Vasiu Constantin; Vasiu Aurel; Sandru Carmen Dana and Niculae Mihaela (2018). Target cell type dependent immune activity of plant extracts in bovine raised under different technologies. Ann. Phytomed., 7(2):81-84.

Manach, C.; Scalbert, A.; Morand, C.; Remes, C. and Jimenez, L. (2004). Polyphenols: Food sources and bioavailability. American Journal of Clinical Nutrition, 79:727-747.

Miliauskas, G; Venskutonis, P.R. and Van-Beek, T.A. (2004). Screening of radical scavenging activity of some medicinal and aromatic plant extracts. Food Chemistry, 85:231-237.

Mokhtari, M.J.; Motamed, N. and Shokrgozar, M.A. (2008). Evaluation of silibinin on the viability, migration and adhesion of the human prostate adenocarcinoma (PC-3) cell line. Cell Bio. Int., 232:888892.

Nada, S.A.; Gowifel.; A.M.H., El-Denshary; E.E.S., Salama,A.A. and Khalil, M.G. (2015). Protective effect of grape seed extract and/or silymarin against thioacetamide-induced hepatic fibrosis in rats. J. Liver, 4:178.

Oyaizu, M. (1986). Studies on product of browning reaction prepared from glucose amine. Jpn. J. Nut., 44:307-315.

Pant, N.C.; Joshi, K.; Kumar, M.; Singh, J.P. and Agrawal, S. (2017). Evaluation of in vitro antioxidant property and phytochemical contents in different genotypes of fenugreek (Trigonella foenum graecum L.). Ann Phytomed., 6(2):126-137.

Parejo, I.; Viladomat, F.; Bastida, J.; Rosas-Romero, A.; Flerlage, N.; Burillo, J. and Codina, C. (2002). Comparison between the radical scavenging activity and antioxidant activity of six distilled and non distilled Mediterranean herbs and aromatic plants. J. Agric. Food Chem., 50:6882-6890.

Prieto, P.; Pineda, M. and Anguilar, M. (1999). Spectrophotometric quantitation of antioxidant capacity through the formation of a phosphomolybdenum complex: Specific application to the determination of Vitamin E. Anal. Biochem., 269:337-341.

Ruch, R.J.; Cheng, S.J. and Klaunig, J.E. (1989). Prevention of cytotoxicity and inhibition of intracellular communication by antioxidant catechin isolated from Chinese green tea. Carcinogenesis, 10:1003-1008.

Seeff, L.B.; Curto, T.M. and Szabo, G. (2008). Herbal product use by persons enrolled in the hepatitis $\mathrm{C}$ antiviral long-term treatment against cirrhosis (HALT-C) trial. Hepatology, 47(2):605-612.

Shahidi and Wanasundara P.D. (1992). Phenolic antioxidants. Critical Review of Food Science and Nutrition, 32:67-103.

Shaker, E.; Mahmoud, H. and Mnaa, S. (2010). Silymarin, the antioxidant component and Silybum marianum extracts prevent liver damage. Food Chem. Toxicol., 48(3):803-806. 
Sharma, G; Singh, R.P. and Chan, D.C. (2003). Silibinin induces growth inhibition and apoptotic cell death in human lung carcinoma cells. Anticancer Res., 23:2649-2655.

Singleton, V.L.; Orthofer, R. and Lamuela-Raventos, R.M. (1999). Analysis of total phenols and other oxidation substrates and antioxidants by means of Folin-Ciocalteu reagent. Methods Enzymol., 299:152-178.

Sofowora, A. (1999). Medicinal Plants and Traditional Medicine in Africa. John Wiley and Son Ltd., pp:150-153.

Sravanthi, J.; Gangadhar Rao, S.; Thirupathi, B. and Venkateshwar, C. (2013). Antioxidant activity of Trigonella foenum-graecum $\mathrm{L}$. for prevention of various diseases. Ann Phytomed., 2(2):85-91.

Sravanthi, J. and Rao, S.G. (2014). Antioxidative studies in Moringa oleifera Lam. Ann Phytomed., 3(2):101-105.

Strader, D.B.; Bacon, B.R. and Lindsay, K.L. (2002). Use of complementary and alternative medicine in patients with liver disease. The American Journal of Gastroenterology, 97(9):2391-2397.
Tanizawa, H.; Ohkawa, Y.; Takino, Y.; Ueno, A.; Kageyama, T. and Hara, S. (1992). Studies on natural antioxidants in citrus species. I; Determination of antioxidant activities of citrus fruits. Chem. Pharm. Bull., 40: 1940-1942.

Trease, G.E. and Evans, W.C. (1993). Textbook of Pharmacognosy. $12^{\text {th }}$ edn. Balliese Tindall and Company Publisher, London, pp:343383.

Zafar, R. and Mujeeb, M. (2002). Retinoid and rutin in callus culture of Tephrosia purpurea pers. Indian J. Pharm. Sci., 3(2):58-61.

Zhishen, J.; Mengcheng, T. and Jianming, W. (1999). The determination of flavonoid contents on mulberry and their scavenging effects on superoxide radical. Food Chem., 64:555-559.

Zongguo, Y.; Liping, Z.; Yunfei, L.; Qingnian, X. and Xiaorong, C. (2014). Effects and tolerance of silymarin (milk thistle) in chronic hepatitis $\mathrm{C}$ virus infection patients: A meta-analysis of randomized controlled trials. Bio. Med. Research International, pp:9.

Citation: Kiran, Pradeep Kumar, Simran Kirti and Altamash Ali Daudi (2019). Phytochemical analysis and antioxidants activity of Silybum marianum (L.) Gaertn. Ann. Phytomed., 8(1):127-134. 